Article

\title{
Investigating Citizen Behavior Intention on Mandatory and Voluntary Pro-Environmental Programs through a Pro-Environmental Planned Behavior Model
}

\author{
Shu-Chiang Lin ${ }^{1, *}$, Reny Nadlifatin ${ }^{1,2}$, Anis Rahmawati Amna ${ }^{2, *}$, Satria Fadil Persada ${ }^{3}$ \\ and Mohammad Razif ${ }^{4}$ \\ 1 Department of Industrial Management, National Taiwan University of Science and Technology, Taipei 106, \\ Taiwan; reny.nadlifatin@gmail.com \\ 2 Department of Informatics Engineering, University of 17 August 1945, Surabaya 60118, Indonesia \\ 3 Department of Business Management, Institut Teknologi Sepuluh Nopember (ITS), Surabaya 60111, \\ Indonesia; satriafadil@mb.its.ac.id \\ 4 Department of Environmental Engineering, Institut Teknologi Sepuluh Nopember (ITS), Surabaya 60111, \\ Indonesia; razif@its.ac.id \\ * Correspondence: slin@mail.ntust.edu.tw (S.-C.L.); anis.r.amna@gmail.com (A.R.A.); \\ Tel.: +886-2-2737-6330 (S.-C.L.); +62-31-592-1516 (A.R.A.)
}

Received: 12 May 2017; Accepted: 18 July 2017; Published: 24 July 2017

\begin{abstract}
The present study was aimed at measuring citizens' behavior intention (BI) regarding mandatory and voluntary pro-environmental programs. Two pro-environmental activities, which consist of an environmental impact assessment (EIA) as a mandatory program and ecolabel products as a voluntary program, were predicted by a pro-environmental planned behavior (PEPB) model. A total of 240 questionnaire data on the EIA subject and 213 questionnaire data on the ecolabel subject were analyzed using structural equation modeling. The analysis results show that the PEPB model is able to describe $60 \%$ of BI regarding the EIA subject and $77 \%$ of citizen BI regarding the ecolabel product subject. Attitude (AT) was revealed to be the lowest direct influence factor of citizen BI regarding the EIA participation result. For the ecolabel products, AT was explored as the strongest factor. Practical suggestions described in this research can be used as a consideration for company management as well as for policy makers to formulate their efforts to improve citizen BI in order to support voluntary and mandatory pro-environmental programs.
\end{abstract}

Keywords: citizens; behavior intention; pro-environmental programs; PEPB

\section{Introduction}

The size of the worldwide population is without a doubt increasing continuously. Hence, many urban activities are performed every year to overcome citizens' needs. These activities, such as the development of buildings, industrialization, infrastructure, and many others, are frequently disturbing and create a negative impact on the environment [1-4]. Since environmental problems are an issue faced by every nation, all the governments worldwide have the essential position to determine the future positive or negative conditions of the environment. However, the role of the government is expected to lengthen the environmental presence for the next generation. Furthermore, governments can issue many regulations at a certain level in order to manage the sustainability of the environment. These regulations can be in the form of mandatory activities, voluntary activities, or even some prohibited policies as a threshold level for both mentioned activities. 
Several research studies describe the positive role of voluntary activities such as the use of environmentally friendly products [5,6], green business [7-10], and many more pro-environmental activities. With regard to mandatory activities, many implementations have been performed. The obligatory requirements include environmental impact assessment (EIA) [11-17], the use of environmental resources as well as their quality and quantity [18,19], and waste management [20,21]. Although both mandatory and voluntary activities are guided by governments or selected agencies, successful pro-environmental activities are also without a doubt influenced by the participation of citizens. Thus, it is important to understand the characteristics from the citizens' perspective. The present study contributes to analyzing citizens' behavior intention in perceiving voluntary and mandatory pro-environmental activities. Two pro-environmental programs, namely EIA and ecolabel products, are examined as the case studies. The pro-environmental planned behavior (PEPB) model is used as the evaluation model. PEPB is an extended version from a famous theory of planned behavior (TPB) model, which considers environmental concern and authority support factors. This study is also the first to analyze both mandatory and voluntary pro-environmental programs by using the PEPB model. Indonesia was selected because as a developing country and the fourth most populated country in the world, Indonesia has much room for improvement in terms of pro-environmental activities. Furthermore, the assessment also serves as a good example for the PEPB model to reveal the latent factors that affect citizens' behavior intention in perceiving pro-environmental activities. If citizens intend to participate in pro-environmental activities, it will help company management as well as policy makers to formulate their efforts to improve citizen BI in order to support the pro-environmental activities.

The following paper is organized as follows. Section 2 describes literatures regarding the elements of PEPB, the EIA and the ecolabel programs in Indonesia. A developed model and the hypotheses are also proposed in this section. Section 3 presents the research methodology. Section 4 explains the data analysis results and several findings of the research. Section 5 encapsulates this study by drawing some conclusions that can be used as references and recommendations for conducting future research.

\section{Theoretical Framework}

PEPB is an extended model introduced by Persada [16] from a behavior model, namely the theory of planned behavior (TPB) [22]. The PEPB is comprised of six factors, namely perceived authority support (PAS), perceived environmental concern (PEC), attitude (AT), subjective norms (SN), perceived behavior control (PBC), and behavior intention (BI), as shown in Figure 1. Most of the construct items in the PEPB model were adapted from the theory of planned behavior (TPB) model (attitude, subjective norms, perceived behavior control, and behavior intention), except for the perceived authority support (PAS) items and perceived environmental concern (PEC) items. Both factors, including the items, were adapted from Persada's [16] dissertation. Persada's research adopts the mentioned factors from thorough studies $[13,14,23]$. Part of the modeling process in Persada's research, which is an extension of the theory of reasoned action (TRA), namely pro-environmental reasoned action (PERA), was tested in Nadlifatin et al.'s research [6].

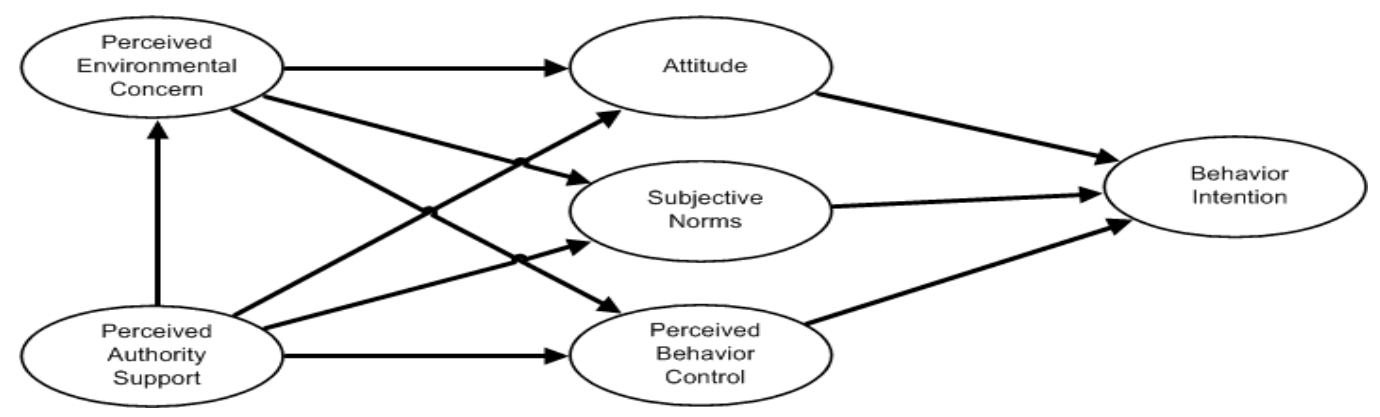

Figure 1. The pro-environmental planned behavior model (PEPB) [16]. 
BI is a depiction factor that is able to describe human efforts to conduct a particular behavior [22]. The intention itself will lead to a particular action [6]. PAS is an individual's perception of any resources, regulations, procedures, and any actions provided by an authority organization or by government that can help individuals to conduct a particular behavior [6,16]. PEC is an individual's feeling regarding any physical action leading to pro-environmental consequences [6,14]. According to Ajzen [22,24], AT can be seen as how the individual express his/her favorable feeling of preferences to perform a particular behavior. $\mathrm{SN}$ is the perceived social pressure, which has a significant influence on the individual's performing a specific behavior. $\mathrm{PBC}$ is the individual's feeling of ease or difficulty of performing a specific behavior.

From the EIA point of view, citizen involvement is one of the required processes needed by the project developer before they can develop a proper project construction. Based on Indonesia's regulations, there are six phases of citizen involvement in the Indonesian EIA process, as shown in Figure 2 [14]. This participation is needed to give the feedbacks from citizens to the project owner as well as to the appointed agencies regarding the field situation issues. Through several regulations [25-28], the Indonesian government ensures the protection of the environment from potential harm by tightening the evaluation process before the project owner gets the environmental permit. The regulations are also designed to conveniently facilitate citizen involvement in the evaluation process. The level of participation is at almost every phase, such as consultation, review (as one of the commission members), as well as suggestions, opinions, and feedback (SOF). The included citizens consist of: (i) the citizens are impacted; (ii) environmentalists; and (iii) citizens affected by all decisions in the EIA process (Ministry of Environment of Indonesian Government Regulation Number 17/2012, chapter 2, point A). Based on the Indonesian Ministry of Environment's government regulation number 5/2012 [25], there are 14 fields that are contained: in this multi-sector: defense; farming; fisheries and marine; forestry; transportation; satellite technology; industries; public works; housing and settlement areas; energy and mineral resources; tourism; nuclear power; and management of hazardous and toxic wastes. Not only the citizens can ensure the environmental safety of their surrounding location, but citizens can also get lots of benefits from the development project. Some benefit examples are employment opportunities, new social interactions, infrastructure improvements, and many more. Thus, the role of authority support is to create a good circumstance where the citizens can participate in pro-environmental programs. Based on the Persada et al. [14] study, the role of authority support positively influences AT, SN, PBC and PEC of citizens in their intention to participate in an EIA. From the AT perspective, the regulations provide the frequent stage of involvement and many options for communication in order to increase the citizens' favorable feeling. From an $\mathrm{SN}$ viewpoint, the regulations serve as a platform to support both the project developer and citizens in working together. From a PBC standpoint, the regulations provide the opportunity for the citizens with the easiest situation to participate in the EIA process. From a PEC perspective, the regulations encourage the citizens' environmental concerns by participating in the EIA assessment.

Therefore, this research identified several hypotheses for mandatory pro-environmental activity as follows:

H1m: PAS has a positive relationship with the AT of citizens in EIA participation behavior.

$\mathbf{H} 2 \mathbf{m}$ : AT has a significant positive relationship to BI of citizens in EIA participation behavior.

H3m: PAS has a significant positive relationship to $\mathrm{SN}$ of citizens in EIA participation behavior.

$\mathbf{H} 4 \mathbf{m}$ : SN has a significant positive relationship to BI of citizens in EIA participation behavior.

H5m: PAS has a significant positive relationship to PBC of citizens in EIA participation behavior.

H6m: $\mathrm{PBC}$ has a significant positive relationship to BI of citizens in EIA participation behavior.

$\mathbf{H 7 m}$ : PAS has a significant positive relationship to PEC of citizens in EIA participation behavior. 


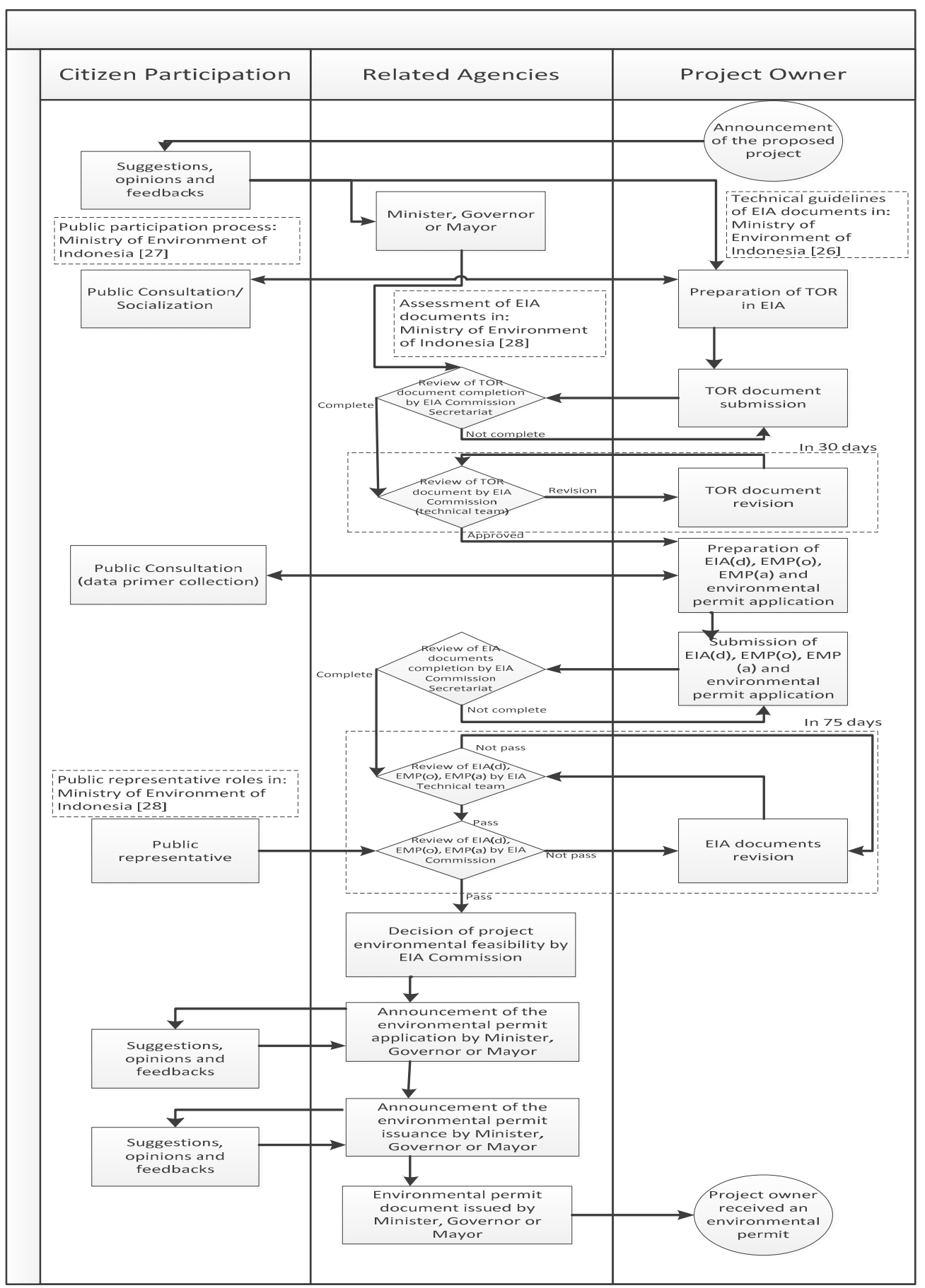

Figure 2. EIA citizen participation process [14].

In the previous research, Persada [16] described the existence of positive relationships between the PEC and the TPB model. Through the PEPB model, the PEC factor serves as the antecedent of the AT, $\mathrm{SN}$, and PBC factors. When citizens have a positive environmental concern, they will have a favorable feeling for the EIA process. A citizen's representative who shares good environmental concern will encourage citizens to participate in the EIA process. Furthermore, positive environmental concern will also drive citizens to ease conditions so citizens will be enthusiastic to participate in the EIA process. Thus, the present research listed several hypotheses for mandatory pro-environmental activity as follows: 
H8m: PEC has a significant positive relationship to AT of citizens in EIA participation behavior. H9m: PEC has a significant positive relationship to SN of citizens in EIA participation behavior. H10m:PEC has a significant positive relationship to BI of citizens in EIA participation behavior.

As for the usage of ecolabel products, citizens have the role of end users who will use the products for daily life. For the currently available Indonesia ecolabel products, there are few varieties such as plastic bags, tissue, carton board, office paper, and furniture [17,29-31]. The imported ecolabel products in Indonesia are, on the contrary, quite numerous compared to the local products, especially for office tools and consumer goods [32]. The evidence from research on customer response to farming products mentioned that ecolabel products have a premium price compared to non-ecolabel products [33]. Although the ecolabel products are relatively more expensive, citizens can take a broader perspective and pick the ecolabel products for the sustainable environment. For instance, citizens need to pay IDR 200 (USD 0.014) extra for a small green plastic bag, as shown in Figure 3. The plastic bag in this example uses a type 2 ecolabel based on ISO 14021 with the name "Ekolabel Swadeklarasi", which means that the company applies one or many environmental parameters that undergo green processes in the product lifecycle $[6,17]$.

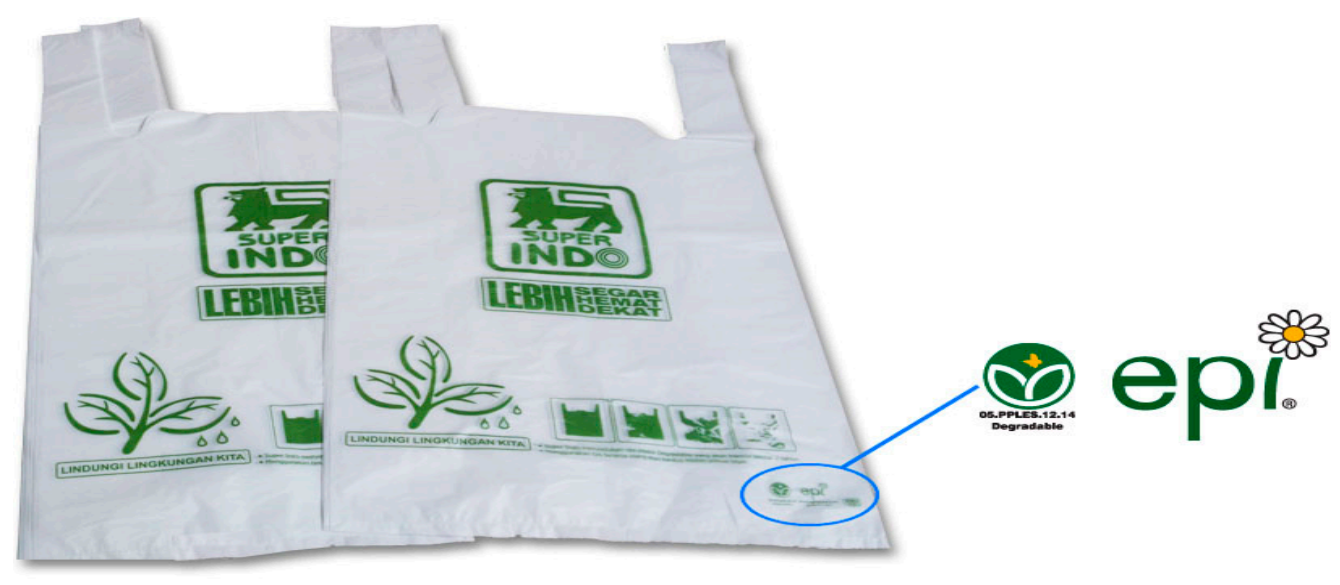

Figure 3. Example of an Indonesian ecolabel product [29].

Based on the Nadlifatin et al. [6] study, there is evidence regarding how the PAS and PEC positively influence the AT and SN of citizens' intentions in ecolabel product usage behavior. Aside from the previous evidence, the regulations also ensure the easiest condition with the support and environmental benefit offers. Thus, the situation provides citizens with good circumstances for the use of ecolabel products. The authorities support the attraction by performing several approaches such as socialization, incentives, and rewards in order to motivate the citizens to use ecolabel products. This government support and environmental concern are believed to be able to positively influence citizens' attitudes, social norms and behavior control. Hence, several hypotheses are provided:

H1v: PAS has a significant positive relationship to AT of citizens in Ecolabel product usage behavior.

H2v: AT has a significant positive relationship to BI of citizens in Ecolabel product usage behavior.

H3v: PAS has a significant positive relationship to SN of citizens in Ecolabel product usage behavior.

H4v: SN has a significant positive relationship to BI of citizens in Ecolabel product usage behavior.

H5v: PAS has a significant positive relationship to PBC of citizens in Ecolabel product usage behavior.

H6v: PBC has a significant positive relationship to BI of citizens in Ecolabel product usage behavior.

H7v: PAS has a significant positive relationship to PEC of citizens in Ecolabel product usage behavior.

H8v: PEC has a significant positive relationship to AT of citizens in Ecolabel product usage behavior.

H9v: PEC has a significant positive relationship to SN of citizens in Ecolabel product usage behavior. H10v: PEC has a significant positive relationship to BI of citizens in Ecolabel product usage behavior. 


\section{Methodology}

This study uses the PEPB model and two questionnaires were designed as an instrument for collecting the data. Both questionnaires were aimed to assess the EIA and ecolabel programs. The questionnaires were comprised of two sections in which the first section included 18 observed variables that were intended to measure six latent factors in the model, as shown in Tables 1 and 2. Specifically, the 18 observed variables, which include PAS, PEC, AT, SN, PBC and BI, were assessed by a five-point Likert scale that ranged from 1 as "I strongly disagree" to 5 as "I strongly agree". The other section was to collect the demographic and background information of the respondents such as their place of origin and age. The EIA questionnaire was administered from November 2013 to April 2014, while the ecolabel questionnaire was administered from January to June 2016. Both online and offline questionnaires were performed by the convenience sampling method on two different projects. The offline EIA data were gathered by one of the authors as an EIA consultant while he was working with seven projects. The projects consisted of a sugar factory, office area, harbor, medical incinerator, industrial area and warehousing. The online EIA data were gathered from online media such as email, social media, online forms and forums. As for the ecolabel data, the offline data were gathered in several campus areas and the online data were gathered by online media. Citizens of Indonesia with a minimum age of 17 years old were targeted. This age was chosen because at age 17 citizens have the full rights to legal action in accordance with the Indonesian constitution and they can legally work to get an income. Structural equation modeling (SEM) was used as the analysis tool. SEM was utilized to assess the structural correlation between interconnected factors. SEM was chosen because of its ability to reveal causal relations in sample data in a path diagram and to solve multiple correlation problems [5,34]. This study also employed confirmatory factor analysis (CFA), which confirmed the positive correlation in the model through the hypothesis statement. Much research on confirmatory factor analysis has been conducted with SEM to validate the influence value on each correlation $[35,36]$. SEM explores ten hypotheses on each program in this study. SPSS and AMOS 20 were used as the analysis tools.

Table 1. EIA questionnaire design $[14,16]$.

\begin{tabular}{cl}
\hline Factors & \multicolumn{1}{c}{ Questions } \\
\hline PAS1 & I feel I have a choice to use the strategies provided by the government for participating in the EIA process. \\
\hline PAS2 & $\begin{array}{l}\text { I feel I have a choice to participate in an environmental program established by the government such as the } \\
\text { EIA process. }\end{array}$ \\
\hline PAS3 & The government endorses the regulation to allow citizens to participate in the EIA process. \\
\hline PEC1 & $\begin{array}{l}\text { I am extremely worried about the state of the world's environment and what it will mean for my future, } \\
\text { so I decided to participate in the EIA process. }\end{array}$ \\
\hline PEC2 & Mankind is severely abusing the environment, hence it makes me want to participate in EIA process. \\
\hline PEC3 & $\begin{array}{l}\text { When humans interfere with nature, it often produces disastrous consequences, it is concerning me to } \\
\text { participate in the EIA process. }\end{array}$ \\
\hline PBC1 & I have the knowledge and time to participate in the EIA process. \\
\hline PBC2 & I have resources, time, ability and opportunities to participate in the EIA process. \\
\hline PBC3 & I have a good confident that if I want, I can participate in the EIA process. \\
\hline SN1 & Most people who are important to me think I should participate in the EIA. \\
\hline SN2 & Most people who are important to me would want me to participate in the EIA process. \\
\hline SN3 & People whose opinions I value would prefer that I participate in the EIA process. \\
\hline AT1 & For me, participating in EIA process when project development occurs is extremely wise. \\
\hline AT2 & For me, participating in EIA process is favorable. \\
\hline AT3 & For me, participating in EIA process is enjoyable. \\
\hline BI1 & I am willing to participate in the EIA process. \\
\hline BI2 & I plan to participate in EIA process when project development is conducted. \\
\hline BI3 & I will make an effort to participate in EIA process. \\
\hline &
\end{tabular}


Table 2. Eco-label products questionnaire design $[6,16]$.

\begin{tabular}{cl}
\hline Factors & \multicolumn{1}{c}{ Questions } \\
\hline PAS1 & $\begin{array}{l}\text { I feel have a chance to use the programs provided by the government or the related authorities with the use } \\
\text { of Ecolabel products in an effort to reduce environmental problems. } \\
\text { The government or the related authorities give me the freedom to make my own decision to use the }\end{array}$ \\
PAS2 & $\begin{array}{l}\text { Ecolabel products. } \\
\text { I feel that I have the option to participate in environmental activities established by the government and } \\
\text { related authorities by using the Ecolabel products. }\end{array}$ \\
PAS3 & $\begin{array}{l}\text { I am very worried about the state of the world environment and what that will mean for my future, so I need } \\
\text { to keep the environment by using the Ecolabel products. }\end{array}$ \\
PEC1 & $\begin{array}{l}\text { Humans are very often misusing/damaging the environment, so it is necessary for me to help save the } \\
\text { PEC2 }\end{array}$ \\
environment by using the Ecolabel products.
\end{tabular}

\section{Results}

\subsection{Data Analysis}

The study collected 240 EIA questionnaires and 213 ecolabel questionnaires. The EIA respondents' ages ranged from 21 to 61, while the ecolabel respondents' ages ranged from 17 to 63. The EIA respondents were from 43 cities, while the ecolabel respondents were from 47 cities in Indonesia. The proportion of gender in the EIA data was 78 males and 162 females, while the gender in the ecolabel data was 80 males and 133 females. The entire respondents were of productive age. A total of 205 respondents were working in the EIA data, while for the ecolabel data this was 170 . The detailed respondent data can be seen in Table 3. Both of the datasets had an average of 3 to 4 , which is from neutral to agree answers, as can be seen in Table 4. From the EIA data, the highest number was recorded as the value of 4.34 (agree), while the lowest number was captured by the value of 3.49 (neutral). As for ecolabel data, the highest data was 4.24 (agree) and the lowest data was 3.33 (neutral). A further data fit test was conducted and three parameters were tested. The three parameters were Cronbach's $\alpha$, composite reliability (CR), and an average variance extracted (AVE). Cronbach's $\alpha$ is a reliable test to detect the consistency of the questions amongst a constructed factor [37]. A CR test assesses reliability using factor loading in its equation [5,38]. An AVE test is the average quantity of variance on observed variables, which describes the variance in a latent construct $[5,6]$. The mentioned parameters have been used in many SEM analysis studies to have threshold values of 0.7, 0.7, 0.7, and 0.5 , accordingly [39-43]. This research shows that most of the parameters have surpassed the minimum threshold, except for PBC3 for the EIA program, and PAS1 as well as PBC1 for the ecolabel program. Therefore, this research performs re-specification by removing the three parameters and performing the second data fit test, as shown in Table 5. In the second data fit test, all results fulfill the minimum threshold, which shows that the data can be used as a basis to simulate the PEPB model. By utilizing structural equation modeling (SEM) analysis, the result values for all correlations were exhibited, as shown in Figures 4 and 5. 
Table 3. Respondent data.

\begin{tabular}{ccc}
\hline Items & EIA & Ecolabel \\
\hline Sample size & 240 & 213 \\
Gender (Male/Female) & $78 / 162$ & $80 / 133$ \\
Age (Productive/retired) & $100 / 0$ & $100 / 0$ \\
Occupation status (y/n) & $205 / 35$ & $170 / 43$ \\
Number of city & 43 & 47 \\
Media (online/offline) & $50 / 190$ & $120 / 93$ \\
\hline
\end{tabular}

Table 4. Descriptive statistic result.

\begin{tabular}{cccccc}
\hline \multirow{2}{*}{ Factor } & \multirow{2}{*}{ Item } & \multicolumn{2}{c}{ EIA } & \multicolumn{2}{c}{ Ecolabel } \\
\cline { 3 - 6 } & & Mean & Stdev & Mean & Stdev \\
\hline \multirow{3}{*}{ PAS } & PAS1 & 3.78 & 0.86 & 3.81 & 0.89 \\
& PAS2 & 3.66 & 0.94 & 3.70 & 1.00 \\
& PAS3 & 3.65 & 0.93 & 3.82 & 0.95 \\
\hline \multirow{3}{*}{ PEC } & PEC1 & 4.14 & 0.86 & 4.24 & 0.93 \\
& PEC2 & 3.94 & 0.93 & 4.22 & 0.83 \\
& PEC3 & 4.13 & 0.81 & 4.14 & 0.91 \\
\hline \multirow{3}{*}{ PBC } & PBC1 & 4.05 & 0.81 & 3.61 & 0.99 \\
& PBC2 & 3.86 & 0.80 & 3.91 & 0.90 \\
& PBC3 & 3.88 & 0.98 & 4.14 & 0.90 \\
\hline \multirow{2}{*}{ SN } & SN1 & 3.60 & 0.91 & 3.41 & 0.99 \\
& SN2 & 3.49 & 0.86 & 3.33 & 0.96 \\
& SN3 & 3.61 & 0.82 & 3.45 & 0.98 \\
\hline \multirow{2}{*}{ AT } & AT1 & 4.15 & 0.82 & 4.21 & 0.90 \\
& AT2 & 4.32 & 0.75 & 3.91 & 0.92 \\
& AT3 & 4.34 & 0.74 & 3.78 & 0.92 \\
\hline \multirow{2}{*}{ BI } & BI1 & 3.99 & 0.80 & 4.15 & 0.88 \\
& BI2 & 3.96 & 0.80 & 4.00 & 0.92 \\
& BI3 & 3.93 & 0.79 & 3.98 & 0.93 \\
\hline \multirow{2}{*}{ PNyyyyy} & & & & &
\end{tabular}

Table 5. Data fit test.

\begin{tabular}{|c|c|c|c|c|c|c|c|c|c|}
\hline \multirow[b]{2}{*}{ Factor } & \multirow[b]{2}{*}{ Item } & \multicolumn{4}{|c|}{ EIA } & \multicolumn{4}{|c|}{ Ecolabel } \\
\hline & & $\begin{array}{c}\text { FL } \\
(\geq 0.7)\end{array}$ & $\begin{array}{c}\alpha \\
(\geq 0.7)\end{array}$ & $\begin{array}{c}\text { CR } \\
(\geq 0.7)\end{array}$ & $\begin{array}{c}\text { AVE } \\
(\geq 0.5)\end{array}$ & $\begin{array}{c}\text { FL } \\
(\geq 0.7)\end{array}$ & $\begin{array}{c}\alpha \\
(\geq 0.7)\end{array}$ & $\begin{array}{c}\text { CR } \\
(\geq 0.7)\end{array}$ & $\begin{array}{c}\text { AVE } \\
(\geq 0.5)\end{array}$ \\
\hline \multirow{3}{*}{ PAS } & PAS1 & 0.73 & \multirow{3}{*}{0.81} & \multirow{3}{*}{0.82} & \multirow{3}{*}{0.60} & - & \multirow{3}{*}{0.76} & \multirow{3}{*}{0.77} & \multirow{3}{*}{0.62} \\
\hline & PAS2 & 0.86 & & & & 0.85 & & & \\
\hline & PAS3 & 0.72 & & & & 0.73 & & & \\
\hline \multirow{3}{*}{ PEC } & PEC1 & 0.77 & \multirow{3}{*}{0.82} & \multirow{3}{*}{0.82} & \multirow{3}{*}{0.61} & 0.88 & \multirow{3}{*}{0.90} & \multirow{3}{*}{0.90} & \multirow{3}{*}{0.76} \\
\hline & PEC2 & 0.79 & & & & 0.91 & & & \\
\hline & PEC3 & 0.78 & & & & 0.82 & & & \\
\hline \multirow{3}{*}{ PBC } & PBC1 & 0.78 & \multirow{3}{*}{0.77} & \multirow{3}{*}{0.77} & \multirow{3}{*}{0.63} & - & \multirow{3}{*}{0.74} & \multirow{3}{*}{0.74} & \multirow{3}{*}{0.59} \\
\hline & PBC2 & 0.80 & & & & 0.72 & & & \\
\hline & PBC3 & - & & & & 0.81 & & & \\
\hline \multirow{3}{*}{$\mathrm{SN}$} & SN1 & 0.76 & \multirow{3}{*}{0.80} & \multirow{3}{*}{0.80} & \multirow{3}{*}{0.58} & 0.82 & \multirow{3}{*}{0.89} & \multirow{3}{*}{0.89} & \multirow{3}{*}{0.74} \\
\hline & SN2 & 0.78 & & & & 0.92 & & & \\
\hline & SN3 & 0.74 & & & & 0.84 & & & \\
\hline \multirow{3}{*}{$\mathrm{AT}$} & AT1 & 0.73 & \multirow{3}{*}{0.84} & & & 0.77 & & & \\
\hline & AT2 & 0.89 & & 0.85 & 0.65 & 0.90 & 0.88 & 0.89 & 0.72 \\
\hline & AT3 & 0.79 & & & & 0.88 & & & \\
\hline & BI1 & 0.80 & & & & 0.89 & & & \\
\hline BI & BI2 & 0.78 & 0.84 & 0.83 & 0.62 & 0.91 & 0.92 & 0.92 & 0.79 \\
\hline & BI3 & 078 & & & & 0.86 & & & \\
\hline
\end{tabular}

FL: Factor Loading with 0.7 threshold; $\alpha$ : Cronbach's alpha with 0.7 threshold; CR: Composite Reliability with 0.7 threshold; AVE: Average Variance Extracted with 0.5 threshold. 


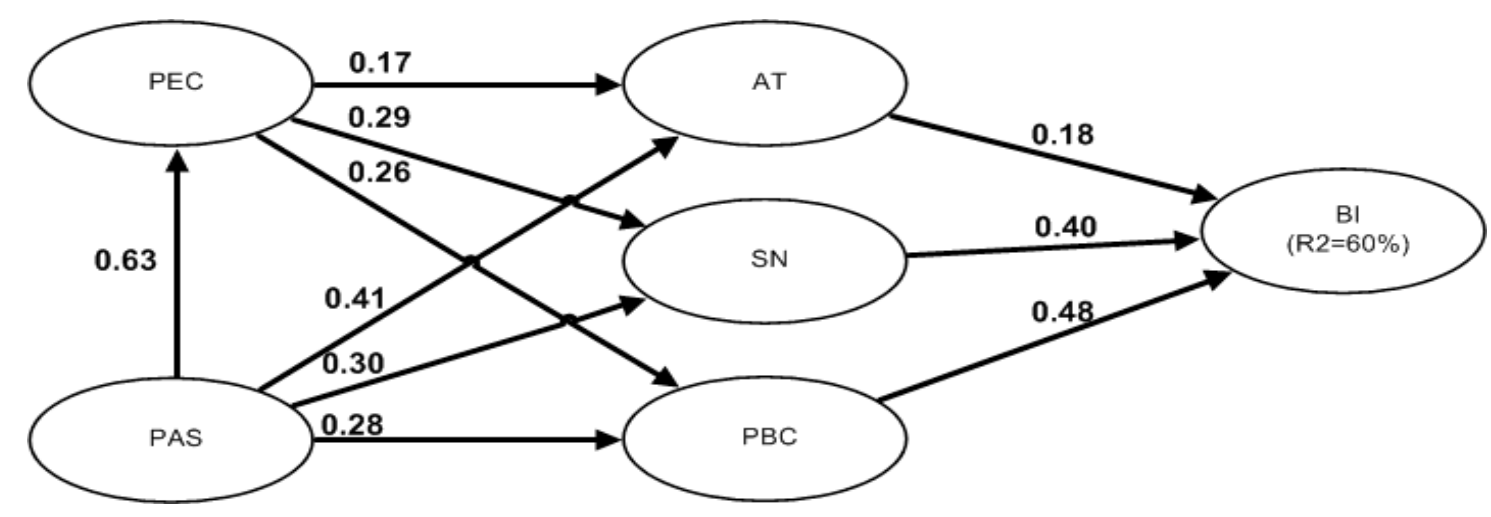

Figure 4. PEPB result for EIA assessment.

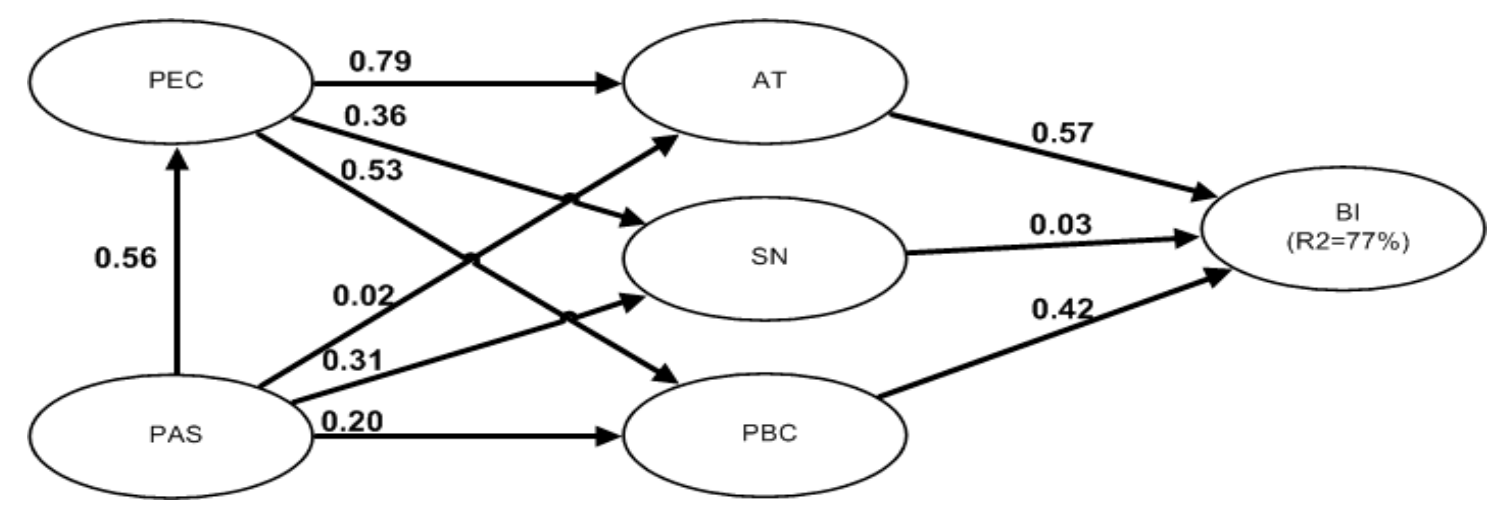

Figure 5. PEPB result for ecolabel product assessment.

A model fit test is conducted to ensure that the constructed model can describe the real condition. Several parameters such as root mean square residual (RMR), goodness of fit (GFI), normed fit index (NFI), comparative fit index (CFI), and normed chi-square $\left(\mathrm{X}^{2} / \mathrm{df}\right)$ can be used for the model fit test $[14,44-46]$. Most of the results show that the values are in the threshold range except for ecolabel GFI, as shown in Table 6. However, several researchers mention 0.8 as the fair value of GFI $[5,47,48]$. To ensure that the resulted SEM has a significant value, a bootstrap test with a maximum likelihood method was performed. A bootstrap method has been utilized by many researchers to see a significant result when the proportion of the sample number was relatively small $(n \leq 400)[5,14,16,43]$. The bootstrap test shows that most of the results have significant values except for the relationship between PEC and AT in EIA, and PAS and AT as well as SN and BI in ecolabel, as shown in Table 7. Therefore, one out of ten hypotheses for EIA was rejected, while there are two out of ten hypotheses in ecolabel that are rejected. The details of the hypothesis validation are shown in Table 8.

Table 6. Model fit result.

\begin{tabular}{cccc}
\hline Model Fit Parameters & EIA & Ecolabel & Threshold \\
\hline Root mean square residual (RMR) & 0.03 & 0.06 & $n \leq 0.08$ \\
Goodness of fit (GFI) & 0.92 & 0.88 & $n \geq 0.80 *$ \\
Normed fit index (NFI) & 0.91 & 0.91 & $n \geq 0.90$ \\
Comparative fit index (CFI) & 0.97 & 0.95 & $n \geq 0.90$ \\
Normed Chi-Squre (X $/$ df) & 1.59 & 2.42 & $n \leq 5.00^{* *}$ \\
\hline$*$ Threshold references: $[5,47,48]^{* *}$ Threshold references: $[44-46]$
\end{tabular}

* Threshold references: $[5,47,48] ;{ }^{* *}$ Threshold references: [44-46]. 
Table 7. Direct and indirect result.

\begin{tabular}{|c|c|c|c|c|c|}
\hline \multirow{2}{*}{ No } & \multirow{2}{*}{ Factors Relationship } & \multicolumn{2}{|c|}{ EIA } & \multicolumn{2}{|c|}{ Ecolabel } \\
\hline & & Direct Effect $(\beta)$ & Indirect Effect $(\beta)$ & Direct Effect $(\beta)$ & Indirect Effect $(\beta)$ \\
\hline 1 & $\mathrm{PEC} \leftarrow \mathrm{PAS}$ & $0.63^{* * *}$ & - & $0.56^{* * *}$ & - \\
\hline 2 & $\mathrm{AT} \leftarrow \mathrm{PAS}$ & $0.41^{* * *}$ & $0.09 *$ & 0.02 & $0.44^{* *}$ \\
\hline 3 & $\mathrm{PBC} \leftarrow \mathrm{PAS}$ & $0.28^{* *}$ & $0.13^{* *}$ & 0.20 * & $0.29 * *$ \\
\hline 4 & $\mathrm{SN} \leftarrow \mathrm{PAS}$ & 0.30 ** & $0.16^{* * *}$ & $0.31 * *$ & 0.20 ** \\
\hline 5 & $\mathrm{BI} \leftarrow \mathrm{PAS}$ & - & $0.38^{* * *}$ & - & $0.48^{* * *}$ \\
\hline 6 & $\mathrm{AT} \leftarrow \mathrm{PEC}$ & 0.17 & - & $0.79 * *$ & - \\
\hline 7 & $\mathrm{PBC} \leftarrow \mathrm{PEC}$ & $0.26^{* *}$ & - & $0.53 * *$ & - \\
\hline 8 & $\mathrm{SN} \leftarrow \mathrm{PEC}$ & $0.29 * * *$ & - & $0.36^{*}$ & - \\
\hline 9 & $\mathrm{BI} \leftarrow \mathrm{PEC}$ & - & $0.25^{* * *}$ & - & $0.68 * *$ \\
\hline 10 & $\mathrm{PBC} \leftarrow \mathrm{AT}$ & - & - & - & - \\
\hline 11 & $\mathrm{SN} \leftarrow \mathrm{AT}$ & - & - & - & - \\
\hline 12 & $\mathrm{BI} \leftarrow \mathrm{AT}$ & $0.18^{* * *}$ & - & $0.57^{* * *}$ & - \\
\hline 13 & $\mathrm{SN} \leftarrow \mathrm{PBC}$ & - & - & - & - \\
\hline 14 & $\mathrm{BI} \leftarrow \mathrm{PBC}$ & $0.48^{* * *}$ & - & $0.42^{* * *}$ & - \\
\hline 15 & $\mathrm{BI} \leftarrow \mathrm{SN}$ & $0.40^{* * *}$ & - & 0.03 & - \\
\hline
\end{tabular}

Table 8. Hypothesis validation.

\begin{tabular}{|c|c|c|c|c|c|}
\hline No & Hypothesis & EIA & Validation & Ecolabel & Validation \\
\hline 1 & $\mathrm{H} 1: \mathrm{AT} \leftarrow \mathrm{PAS}$ & Positive, Significant & Accepted & Positive, Insignificant ** & Rejected \\
\hline 2 & $\mathrm{H} 2: \mathrm{BI} \leftarrow \mathrm{AT}$ & Positive, Significant & Accepted & Positive, Significant & Accepted \\
\hline 3 & $\mathrm{H} 3: \mathrm{SN} \leftarrow \mathrm{PAS}$ & Positive, Significant & Accepted & Positive, Significant & Accepted \\
\hline 4 & $\mathrm{H} 4: \mathrm{BI} \leftarrow \mathrm{SN}$ & Positive, Significant & Accepted & Positive, Insignificant ${ }^{* * *}$ & Rejected \\
\hline 5 & $\mathrm{H} 5: \mathrm{PBC} \leftarrow \mathrm{PAS}$ & Positive, Significant & Accepted & Positive, Significant & Accepted \\
\hline 6 & H6: $\mathrm{BI} \leftarrow \mathrm{PBC}$ & Positive, Significant & Accepted & Positive, Significant & Accepted \\
\hline 7 & H7: PEC $\leftarrow$ PAS & Positive, Significant & Accepted & Positive, Significant & Accepted \\
\hline 8 & $\mathrm{H} 8: \mathrm{AT} \leftarrow \mathrm{PEC}$ & Positive, Insignificant * & Rejected & Positive, Significant & Accepted \\
\hline 9 & $\mathrm{H} 9 \mathrm{SN} \leftarrow \mathrm{PEC}$ & Positive, Significant & Accepted & Positive, Significant & Accepted \\
\hline 10 & $\mathrm{H} 10: \mathrm{PBC} \leftarrow \mathrm{PEC}$ & Positive, Significant & Accepted & Positive, Significant & Accepted \\
\hline
\end{tabular}

\subsection{Discussion}

The analysis results reveal positive correlations in the PEPB model for the assessment of EIA and ecolabel products. Nine from ten correlations in the EIA assessment have positive and significant values, while eight from ten correlations in the assessment of ecolabel products have positive and significant values. The significant correlation between PAS and AT for both EIA and ecolabel products $\left(\beta_{\text {(EIA)PAS } \rightarrow \text { PEC }}=0.63 ; \beta_{(\text {Ecolabel }) \text { PAS } \rightarrow \text { PEC }}=0.56\right)$ indicates the major influence of the government in influencing citizens' pro-environmental concerns. This situation can be seen as a good condition, where all the support given by the government for mandatory and voluntary programs can be perceived positively in citizens' environmental behavior. It is also confirmed that all the support strategies given by the government are conducted on the right track for environmental awareness. Similar situations also occur from authority support for citizens' PBC as well as citizens' SN for both EIA and ecolabel products. Although the values are relatively low for the PBC $\left(\beta_{(\mathrm{EIA}) \mathrm{PAS} \rightarrow \mathrm{PBC}}=0.28\right.$;

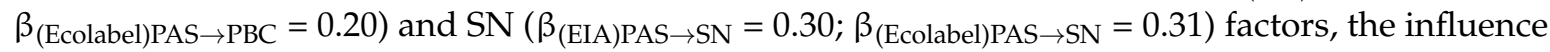
of authority support is still captured by citizens as positive and significant.

The first interesting finding in this study is the different correlation results from PAS to AT on

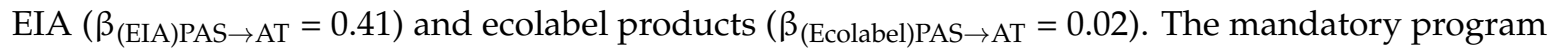
has a high and significant value, while the voluntary program has a low and insignificant value. A possible cause of this situation is the limited varieties of ecolabel products for fulfilling citizens' needs. The differences of quality and cost between non-ecolabel products and ecolabel products, 
besides the limited product varieties, also possibly contributes a low value to citizen attitude. Some suggestions for authority support in this situation are providing support to enlarge the variety of ecolabel products, improve the quality as well as adding a subsidy to ensure that the ecolabel products can compete with the non-ecolabel products.

The second interesting finding in this study is the opposite result from the first finding, where the correlation from PEC to AT for EIA ( $\beta_{(\text {EIA)PEC } \rightarrow \text { AT }}=0.17$ ) is insignificant and PEC to AT for ecolabel products $\left(\beta_{(\text {Ecolabel)PEC } \rightarrow A T}=0.79\right)$ is significant. These findings, perhaps, reflect a situation where the citizens perceived a lower favorable in environmental concern when the pro-environmental activity is obligated rather than voluntary. Furthermore, not only the perceived score from PEC to AT in the mandatory program is low, but the contributed score from AT to BI in the mandatory program is also low $\left(\beta_{(\mathrm{EIA}) \mathrm{AT} \rightarrow \mathrm{BI}}=0.18\right)$. On the contrary, both the perceived score from PEC to AT and the contributed score from AT to BI in the voluntary program show a good value $\left(\beta_{(\text {Ecolabel }) A T \rightarrow B I}=0.57\right)$. Therefore, the third interesting finding in this study is that the AT factor provides a minor contribution to citizens' $\mathrm{BI}$ in the mandatory program, whereas in the voluntary program, the AT factor provides a major contribution to citizens' BI. To overcome the second and third findings, ensuring citizens understand that both mandatory and voluntary programs require the same concern is important (i.e., a mandatory environmental program does not imply that the activity shall be fully charged to the appointed agency and the citizens only contribute a minor portion). A recommendation such as improving good environmental education for citizens is highly suggested. On the next correlations, the mandatory and voluntary programs have positive and significant values, both from PEC to $\mathrm{SN}\left(\beta_{(\mathrm{EIA}) \mathrm{PEC} \rightarrow \mathrm{SN}}=0.29\right.$;

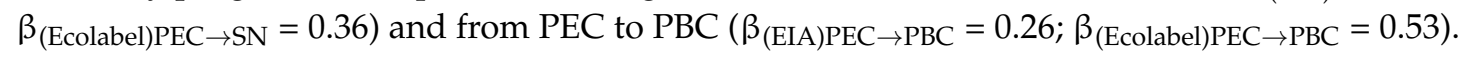

The fourth and the last finding in this study is the different value of $\mathrm{SN}$ to $\mathrm{BI}$ on both mandatory $\left(\beta_{(\mathrm{EIA}) \mathrm{SN} \rightarrow \mathrm{BI}}=0.40\right.$, significant $)$ and voluntary $\left(\beta_{(\text {Ecolabel }) \mathrm{SN} \rightarrow \mathrm{BI}}=0.03\right.$, insignificant $)$ programs. This situation might be happening because most of the mandatory programs involve community representatives such as a community leader (Ketua RT, RW, Lurah), the head of a district, and public figures. The community representatives tend to have a strong influence on the SN of citizens. On the other hand, the voluntary program is strongly dependent on an individual without much intervention from SN. The same recommendation as from the previous finding regarding good environmental education is suggested. The last correlation from PBC to BI in both the mandatory and voluntary programs has a positive and significant value $\left(\beta_{(\mathrm{EIA}) \mathrm{PBC} \rightarrow \mathrm{BI}}=0.48 ; \beta_{(\text {Ecolabel }) \mathrm{PBC} \rightarrow \mathrm{BI}}=0.42\right)$. The result indicates that the citizens have an easy situation in participating in both voluntary and mandatory programs. Finally, the PEPB model consisted of six factors able to describe $60 \%$ of total citizens' intention in mandatory as well as $77 \%$ of total citizens' intention in voluntary programs. The other $40 \%$ and $23 \%$ influences might come from the factors outside the PEPB model. The value of squared multiple correlation (R2) is comparable to other pro-environmental research that using SEM as the analysis tool $[6,14,34,49,50]$.

\subsection{Managerial Implications}

The PEPB model describes a set of factors influencing citizens' intention to participate in mandatory and voluntary pro-environmental activities. The decision-makers, such as a government appointed agencies and companies, can manipulate these factors to stimulate citizens' intentions to participate. In particular, our findings about the EIA low value for PEC $\rightarrow$ AT $\rightarrow$ BI suggest that the appointed agency should educate citizens regarding the importance of concerning the environment by participating in EIA programs. In addition, the appointed agency should also urge the project companies to socialize intensively regarding their projects, including both the benefit and the importance values, to attract citizens. Not restricted to education and socialization approaches, the appointed agency can also strictly accompany the whole process to ensure good involvement.

The next managerial suggestions for ecolabel products are to focus on how to manipulate the value for PEC $\rightarrow \mathrm{AT} \rightarrow \mathrm{BI}$. Apparently, citizens greatly desire to buy ecolabel products. However, since the varieties of the products are limited, the government should create the best environment 
for companies to create environmentally friendly products. Some incentives and an easy process of ecolabel certification, as well as promoting green movements, should be conducted more often. Thus, when the business environment supports the creation of more green products, the number of varieties will grow naturally.

\section{Conclusions}

The present research investigated citizens' behavior intention for mandatory and voluntary pro-environmental programs by using the pro-environmental planned behavior (PEPB) model. The PEPB model is an extended model of TPB [16,22] with perceived authority support (PAS) and perceived environmental concern (PEC) factors considered. Two pro-environmental programs, environmental impact assessment (EIA) and ecolabel products, were selected as case studies. The result reveals that the AT factor has a minor influence in the mandatory program, while in the voluntary program AT has a major influence. Several suggestions emerge from this study, such as that the appointed agency should educate citizens regarding the importance of showing concern about the environment by participating in EIA programs. The appointed agency should also strictly accompany the whole process and project companies are urged to socialize intensively regarding their projects, both the benefit and the importance values, to attract citizens. The authorities should provide support to enlarge the varieties of ecolabel products and improve the quality, as well as adding a subsidy to ensure that the ecolabel products can compete with the non-ecolabel products. Another recommendation is also suggested, namely ensuring that citizens understand that both mandatory and voluntary programs require the same concern, which is important in a good environmental education.

In conclusion, the present research confirms the suitability of applying the PEPB model to analyze citizen BI for mandatory and voluntary pro-environmental programs. Nine out of ten hypotheses were approved for the mandatory case and eight out of ten hypotheses were approved for the voluntary case. Increasing citizens intention for mandatory and voluntary pro-environmental programs will help to ensure the sustainability of the environment. The limitation of this study appears in the respondent background, such as education, awareness of the environment, and the culture that the citizens have. In a developing country, the results of the PEPB model might be different than in a developed country. Different case studies for the mandatory and voluntary pro-environmental programs would probably produce different results for this study. Finally, future research should explore the other $40 \%$ and $23 \%$ latent contributions, which might be affected by other factors outside the PEPB model. Further future research can be performed by investigating the citizens' intention level for mandatory and voluntary pro-environmental programs with the PEPB model in a developed country for a comparison study.

Acknowledgments: The authors would like to thank the two anonymous reviewers who provided their insight on the final versions of the manuscript.

Author Contributions: Shu-Chiang Lin guided the research scope, methodology and research process, gave final review suggestions of the manuscript; Reny Nadlifatin and Anis R. Amna performed research, analyzed the data, and wrote the manuscript; Satria Fadil Persada and Mohammad Razif shares the knowledge and information in terms of pro-environmental research, especially EIA and ecolabel research. All authors read and approved the final manuscript.

Conflicts of Interest: The authors declare no conflict of interest.

\section{References}

1. El Araby, M. Urban growth and environmental degradation: The case of Cairo, Egypt. Cities 2002, 19, 389-400. [CrossRef]

2. Xian, G.; Crane, M.; Su, J. An analysis of urban development and its environmental impact on the Tampa Bay watershed. J. Environ. Manag. 2007, 85, 965-976. [CrossRef] [PubMed]

3. Razif, M.; Moesriati, A.; Nadlifatin, R. A System Dynamics Assessment on the Dispersion of Incinerator Pollutant Emission from Environmental Impact Assessment (EIA) Study: A Case of Medical Waste in Sidoarjo Regency. Int. J. ChemTech Res. 2016, 9, 249-256. 
4. Razif, M.; Persada, S.F. The Calculation of Average Vehicles Emission from Environmental Audit in Toll-Road Surabaya-Gresik at Indonesia. Int. J. ChemTech Res. 2016, 9, 657-668.

5. Lin, S.C.; Persada, S.F.; Nadlifatin, R.; Tsai, H.Y.; Chu, C.H. Exploring the influential factors of manufacturers' initial intention in applying for the green mark Ecolabel in Taiwan. Int. J. Precis. Eng. Manuf. Green Technol. 2015, 2, 359-364. [CrossRef]

6. Nadlifatin, R.; Lin, S.C.; Rachmaniati, Y.P.; Persada, S.F.; Razif, M. A Pro-Environmental Reasoned Action Model for Measuring Citizens' Intentions regarding Ecolabel Product Usage. Sustainability 2016, 8, 1165. [CrossRef]

7. Kirchhoff, S. Green business and blue angels. Environ. Resour. Econ. 2000, 15, 403-420. [CrossRef]

8. Font, X.; Tribe, J. Promoting green tourism: The future of environmental awards. Int. J. Tour. Res. $2001,3,9$. [CrossRef]

9. Ghose, A.; Hoesch-Klohe, K.; Hinsche, L.; Le, L.S. Green business process management: A research agenda. Australas. J. Inf. Syst. 2009, 16. [CrossRef]

10. Hendry, J.R.; Vesilind, P.A. Ethical motivations for green business and engineering. Clean Technol. Environ. Policy 2005, 7, 252-258. [CrossRef]

11. Tang, S.-Y.; Ching, P.T.; Carlos, W.-L. Public participation and environmental impact assessment in mainland China and Taiwan: Political foundations of environmental management. J. Dev. Stud. 2005, 41, 1-32. [CrossRef]

12. Persada, S.F.; Razif, M.; Lin, S.C.; Nadlifatin, R. Toward Paperless Public Announcement on Environmental Impact Assessment (EIA) through SMS Gateway in Indonesia. Procedia Environ. Sci. 2014, 20, 271-279. [CrossRef]

13. Nadlifatin, R.; Razif, M.; Lin, S.C.; Persada, S.F.; Belgiawan, P.F. An assessment model of Indonesian citizens' intention to participate on environmental impact assessment (EIA): A behavioral perspective. Procedia Environ. Sci. 2015, 28, 3-10. [CrossRef]

14. Persada, S.F.; Lin, S.C.; Nadlifatin, R.; Razif, M. Investigating the citizens' intention level in environmental impact assessment participation through an extended theory of planned behavior model. Glob. NEST J. 2015, 17, 847-857.

15. Persada, S.F.; Lin, S.C.; Nadlifatin, R.; Razif, M. A Lean Based Analysis on the Indonesian Citizens' Participation in Environmental Impact Assessment (EIA): A Potential Improvement through Web Based System and SMS-Gateway. Available online: http://is.its.ac.id/pubs/oajis/index.php/home/detail/1512/ A-lean-based-analysis-on-the-Indonesian-citizens-participation-in-environmental-impact-assessmentEIA-a-potential-improvement-through-web-based-system-and-SMS-gateway (accessed on 20 April 2017).

16. Persada, S.F. Pro Environmental Planned Behavior Model to Explore the Citizens' Participation Intention in Environmental Impact Assessment: An Evidence Case in Indonesia. Ph.D. Thesis, Industrial Management Department, National Taiwan University of Science and Technology, Taipei, Taiwan, 2016.

17. Razif, M.; Persada, S.F. Environmental Impact Assessment (EIA) Framework for Ekolabel Certification Initiative in Indonesia: Case Study of a Rattan-Plywood Based Furniture Industry. Int. J. ChemTech Res. 2016, 9, 634-643.

18. Razif, M.; Persada, S.F. The Fluctuation Impacts of BOD, COD and TSS in Surabaya's Rivers to Environmental Impact Assessment (EIA) Sustainability on Drinking Water Treatment Plant in Surabaya City. Int. J. ChemTech Res. 2015, 8, 143-151.

19. Razif, M.; Persada, S.F. An Investigation of Water Compounds Behavior in Drinking Water Treatment Technology for Environmental Impact Assessment (EIA) Strategy: A Case Study on Surabaya. Int. J. ChemTech Res. 2016, 9, 327-331.

20. Razif, M.; Yanuwiadi, B.; Rachmansyah, A.; Persada, S.F. Prediction of Wastewater Fluctuations in Wastewater Treatment Plant by a System Dynamic Simulation Approach: A Projection Model of Surabaya's Mall. Int. J. ChemTech Res. 2015, 8, 2009-2018.

21. Razif, M.; Persada, S.F. An evaluation of Wastewater Compounds Behavior to Determine the Environmental Impact Assessment (EIA) Wastewater Treatment Plant Technology Consideration: A Case on Surabaya Malls. Int. J. ChemTech Res. 2015, 8, 371-376.

22. Ajzen, I. The theory of planned behavior. Organ. Behav. Hum. Decis. Process. 1991, 50, 179-211. [CrossRef]

23. Chen, M.F.; Tung, P.J. Developing an extended theory of planned behavior model to predict consumers' intention to visit green hotels. Int. J. Hosp. Manag. 2014, 36, 221-230. [CrossRef] 
24. Ajzen, I. From intentions to actions: A theory of planned behavior. In Action Control; Springer: Berlin/Heidelberg, Gremany, 1985; pp. 11-39.

25. Ministry of Environment of Indonesia. Ministry of Environment of Indonesian Government Regulation Number 05/2012: Type of Business Plan and or Activities Required to Have an Environmental Impact Assessment; Indonesia Ministry of Environment Regulation Archives: Jakarta, Indonesia, 2012.

26. Ministry of Environment of Indonesia. Ministry of Environment of Indonesian Government Regulation Number 16/2012: Guidelines for Environmental Document Arrangement; Indonesia Ministry of Environment Regulation Archives: Jakarta, Indonesia, 2012.

27. Ministry of Environment of Indonesia. Ministry of Environment of Indonesian Government Regulation Number 17/2012: Guidelines for Community Involvement in Environmental Impact Assessment Process and Environmental Permit; Indonesia Ministry of Environment Regulation Archives: Jakarta, Indonesia, 2012.

28. Ministry of Environment of Indonesia. Ministry of Environment of Indonesian Government Regulation Number 08/2013: Procedures on Assessment and Environmental Document Inspection Plus the Environmental Permit Issuance; Indonesia Ministry of Environment Regulation Archives: Jakarta, Indonesia, 2013.

29. Merindo. Indonesian Government Recognitions by Ecolabel Certificate. Available online: http:/ / www.merindo.co.id/index.php/61-en/products-solutions/pns-env/pns-env-oxobiodegradable/ 101-epi-oxo-biodegradable-plastic-additives-indonesian-government-recognition-certificates (accessed on 15 June 2017).

30. Ministry of Environment of Indonesia. Certifications from National Committee Accreditation and Ekolabel Indonesia. Available online: http://www.menlh.go.id/sertifikasi-kan-dan-ekolabel-indonesia/ (accessed on 15 June 2017).

31. National Standardization Agency. Hundreds of Furniture Companies Own the Ecolabel. Available online: http:/ / www.bsn.go.id/main/berita/berita_det/814/Perlu-standardisasi-agar-tak-salah-kaprah\# .WUKHOuuGNdg (accessed on 15 June 2017).

32. Ministry of Environment of Indonesia. Challenges and Opportunities of Indonesia's Ecolabel in the Era of Globalization. Available online: http://www.menlh.go.id/tantangan-dan-peluang-ekolabel-indonesia-diera-globalisasi/ (accessed on 15 June 2017).

33. Mariyono, J. Tanggapan konsumen terhadap eco-label pada produk pertanian (response of consumers to eco-label on farming product). In Proceedings of the National Seminar of Agribusiness and Rural Economic Development 1, Bangkalan, Indonesia, 21 May 2014; pp. 14-20.

34. McDonald, R.P.; Ho, M.H.R. Principles and practice in reporting structural equation analyses. Psychol. Methods 2002, 7, 64. [CrossRef] [PubMed]

35. Schreiber, J.B.; Nora, A.; Stage, F.K.; Barlow, E.A.; King, J. Reporting structural equation modeling and confirmatory factor analysis results: A review. J. Educ. Res. 2006, 99, 323-338. [CrossRef]

36. Jackson, D.L.; Gillaspy, J.A., Jr.; Purc-Stephenson, R. Reporting practices in confirmatory factor analysis: An overview and some recommendations. Psychol. Methods 2009, 14, 6. [CrossRef] [PubMed]

37. Cronbach, L.J. Coefficient alpha and the internal structure of tests. Psychometrika 1951, 16, 297-334. [CrossRef]

38. Shook, C.L.; Ketchen, D.J.; Hult, G.T.M.; Kacmar, K.M. An assessment of the use of structural equation modeling in strategic management research. Strateg. Manag. J. 2004, 25, 397-404. [CrossRef]

39. Chin, J.; Lin, S.C. Investigating users' perspectives in building energy management system with an extension of technology acceptance model: A case study in Indonesian manufacturing companies. Procedia Comput. Sci. 2015, 72, 31-39. [CrossRef]

40. Chin, J.; Lin, S.C. A Behavioral Model of Managerial Perspectives Regarding Technology Acceptance in Building Energy Management System. Sustainability 2016, 8, 641. [CrossRef]

41. Gefen, D.; Straub, D.; Boudreau, M.C. Structural equation modeling and regression: Guidelines for research practice. Commun. Assoc. Inf. Syst. 2000, 4, 7.

42. Fornell, C.; Larcker, D.F. Evaluating structural equation models with unobservable variables and measurement error. J. Mark. Res. 1981, 18, 39-50. [CrossRef]

43. Lin, S.C.; Persada, S.F.; Nadlifatin, R. A study of student behavior in accepting the Blackboard Learning System: A Technology Acceptance Model (TAM) approach. In Proceedings of the IEEE 18th International Conference on Computer Supported Cooperative Work in Design (CSCWD), Hsinchu, Taiwan, 21-23 May 2014; pp. 457-462. 
44. Hooper, D.; Coughlan, J.; Mullen, M. Structural equation modelling: Guidelines for determining model fit. Electron. J. Bus. Res. Methods 2008, 6, 53-60.

45. Moss, S. Fit Indices for Structural Equation Modeling. Available online: http://www.sicotests.com/ psyarticle.asp?id=277 (accessed on 15 June 2017).

46. Ullman, J.B. Structural equation modeling. In Using Multivariate Statistics, 4th ed.; Tabachnick, B.G., Fidell, L.S., Eds.; Allyn \& Bacon: Needham Heights, MA, USA, 2001; pp. 653-771.

47. Hsu, C.L.; Lin, J.C.C. Acceptance of blog usage: The roles of technology acceptance, social influence and knowledge sharing motivation. Inf. Manag. 2008, 45, 65-74. [CrossRef]

48. Jani, M.A.; Sari, G.I.P.; Pribadi, R.C.H.; Nadlifatin, R.; Persada, S.F. An investigation of the influential factors on digital text voting for commercial competition: A case of Indonesia. Procedia Comput. Sci. 2015, 72, 285-291. [CrossRef]

49. Bamberg, S. How does environmental concern influence specific environmentally related behaviors? A new answer to an old question. J. Environ. Psychol. 2003, 23, 21-32. [CrossRef]

50. Han, H.; Hsu, L.-T.; Sheu, C. Application of the Theory of Planned Behavior to green hotel choice: Testing the effect of environmental friendly activities. Tour. Manag. 2010, 31, 325-334. [CrossRef]

(C) 2017 by the authors. Licensee MDPI, Basel, Switzerland. This article is an open access article distributed under the terms and conditions of the Creative Commons Attribution (CC BY) license (http:/ / creativecommons.org/licenses/by/4.0/). 